\title{
ANALISIS NONCONFORMING PART PADA WING STRUCTURE PESAWAT CN-235 DENGAN MENGGUNAKAN METODE FMEA (FAILURE MODE EFFECT ANALYSIS)
}

\author{
Much. Djunaidi*), Andrew Krishna Ryantaffy \\ Prodi Teknik Industri, Universitas Muhammadiyah Surakarta \\ Jalan Ahmad Yani, Pabelan, Kartasura, Solo 57162
}

(Received: October 01, 2017/Accepted: May, 31, 2018)

\begin{abstract}
Abstrak
Transportasi udara menjadi moda trasportasi yang terus berkembang di Indonesia. Dukungan terhadap sistem transportasi udara yang aman sangat dibutuhkan. Oleh karena itu, proses pembuatan pesawat terbang yang dilakukan di PT. Dirgantara Indonesia perlu terus dijaga kualitasnya. Artikel ini membahas masalah kecacatan komponen rib pada wing structure pesawat CN235 pada saat proses perakitan struktur sayap pesawat. Data menunjukkan bahwa komponen yang banyak mengalami kegagalan adalah rib, dengan tingkat keparahan yang ditimbulkan masuk dalam kategori fatal. Dengan menggunakan pendekatan failure mode effect analysis, kasus terjadinya rib yang tidak sesuai menjadi bentuk modus kegagalan yang menjadi prioritas perbaikan dengan nilai RPN yang tertinggi dibandingkan dengan modus-modus kegagalan lainnya. Alternatif solusi untuk mengatasi masalah tersebut adalah dengan melakukan inspeksi yang lebih ketat terhadap komponen khusus, serta melakukan analisis untuk faktor-faktor yang lain.
\end{abstract}

Kata kunci: FMEA; Struktur sayap; Komponen rib; Keselamatan penerbangan

\begin{abstract}
[Analysis of Non-conforming Part on Wing Structure Aircraft CN-235 Using FMEA (Failure Modes Effect Analysis) Method] Air transportation is becoming a growing transportation mode in Indonesia. Support for safe air transport systems is needed. Therefore, the process of making aircraft that is done in PT. Dirgantara Indonesia needs to keep its quality. This article discusses the problem of the components of the rib component in the wing structure of the CN235 aircraft during the assembly process of the aircraft wing structure. The data indicate that the components that many fail are rib, with the severity generated into the fatal category. By using the failure mode effect analysis approach, the case of incompatible rib becomes the form of failure mode that becomes the priority of improvement with the highest RPN value compared to other failure modes. Alternative solutions to overcome these problems is to conduct more rigorous inspections of specific components, as well as perform analysis for other factors.
\end{abstract}

Keywords: FMEA; Wing structure; Rib component; Safety flight

\footnotetext{
*) Penulis Korespondensi.

E-mail: much.djunaidi@ums.ac.id
} 


\section{Pendahuluan}

Indonesia merupakan sebuah negara yang luas yang terdiri dari berbagai macam pulau. Dengan kondisi geografis yang sedemikian rupa mengakibatkan meningkatnya kebutuhan dari segi alat transportasi, baik transportasi darat, laut maupun udara. Salah satu alat transportasi yang familiar oleh masyarakat Indonesia adalah alat transportasi udara dengan menggunakan pesawat terbang. Pesawat terbang merupakan alat transportasi udara yang cukup diminati oleh masyarakat Indonesia dikarenakan memiliki jalur akses yang cepat serta memiliki waktu tempuh yang relatif singkat. Dalam proses pembuatan pesawat terbang, kualitas merupakan faktor yang paling utama untuk dipertimbangkan, sebab pesawat terbang merupakan alat transportasi yang memiliki tingkat resiko yang cukup tinggi dikarenakan menggunakan udara sebagai jalur aksesnya. Menurut Assauri (2004), pengendalian kualitas merupakan kegiatan-kegiatan untuk memastikan apakah kebijaksanaan dalam hal mutu atau standar dapat tercermin dalam hasil akhir. Dengan kata lain pengendalian mutu adalah usaha mempertahankan kualitas dan barang yang dihasilkan, agar sesuai dengan spesifikasi produk yang telah ditetapkan berdasarkan kebijaksanaan pemimpin perusahaan (Nastiti, 2013)

PT. Dirgantara Indonesia (PT. DI) merupakan perusahaan yang bergerak pada industri penerbangan yang memiliki peranan penting di Indonesia. PT. DI adalah satu-satunya perusahaan yang menciptakan produk pesawat terbang di Indonesia. Perusahaan harus memperhatikan beberapa aspek yang berkaitan dengan kualitas. Industri pesawat terbang harus menerapkan prinsip 'safe flight', karena keamanan penerbangan sangat diutamakan (Bala, dkk., 2014). Perusahaan harus dapat menjamin bahwa produk yang dihasilkan memiliki kualitas terbaik. Salah satu aspek yang perlu diperhatikan adalah adanya defect atau kecacatan produk. Kecacatan produk sangat berpengaruh dalam proses produksi. Kecacatan yang ringan mungkin masih dapat dilakukan rework (pengerjaan ulang). Namun apabila kecacatan tersebut di luar kendali atau tidak memungkinkan untuk dilakukan pengerjaan ulang, maka produk tersebut sudah tidak dapat digunakan (Agnihothri \& Kenett, 1995), yang berdampak pada penambahan biaya di sektor produksi (Ezeanyim, dkk., 2015) dan mempengaruhi waktu proses produksi (Chen, 2013). Hal tersebut juga terjadi pada saat produksi pesawat jenis CN-235, yang menyebabkan komponen yang sudah diproduksi tidak dapat dilakukan pengerjaan ulang dikarenakan komponen tersebut masuk dalam kategori scrap atau ditolak.

Analisis dan evaluasi untuk mengetahui penyebab suatu masalah dapat menggunakan beberapa metode. Salah satunya adalah dengan metode failure mode and effect analysis (FMEA). FMEA adalah sebuah teknik yang digunakan untuk menetapkan, mengidentifikasi, dan menghilangkan kegagalan yang diketahui, permasalahan, error, dan sejenisnya dari sebuah sistem, desain, proses, dana atau jasa sebelum mencapai konsumen (Stamatis, 2003).

Pendekatan FMEA telah banyak digunakan untuk melakukan analisis kualitas produk dan juga mengajukan usulan perbaikan untuk mengatasi permasalahan kualitas tersebut. Hanif, dkk (2015) menggunakan pendekatan FMEA untuk memperbaiki kualitas produk kotak parfum pada sebuah perusahaan berbasis handmade manufacturer. Pendekatan FMEA digunakan untuk mengidentifikasi jenis kegagalan dan mengukur tingkat resiko dari kegagalan yang terjadi pada proses produksi yang bersifat manual.

Puspitasari dan Martanto (2014) menggunakan FMEA untuk menganalisis kegagalan proses produksi sarung tenun dengan menggunakan alat tenun mesin (ATM). Metode ini mengidentifikasi jenis kegagalan yang terjadi pada proses produksi dengan mesin yang bekerja secara otomatis, disertai dengan usulan untuk perbaikannya. Pendekatan FMEA untuk analisis proses produksi dengan mengintegrasikan lean production juga dapat dilakukan (Banduka, dkk., 2016). Metode FMEA juga dapat digunakan untuk melakukan analisis kegagalan komponen untuk keperluan perawatan mesin. Perawatan komponen yang ada pada excavator tipe 390D yang dioperasikan pada pertambangan nikel di Soroako (Darmawan, dkk., 2016).

Pada proses produksi komponen untuk wing structure pada pesawat jenis $\mathrm{CN}-235$ yang dilaksanakan di PT. DI, masih ditemui adanya komponen yang mengalami kecacatan dan masuk dalam kategori nonconforming, sehingga harus dilakukan reject. Hal ini tentu menimbulkan pemborosan pada proses produksi pesawat $\mathrm{CN} 235$.

Artikel ini akan melakukan analisis dan evaluasi penyebab adanya komponen yang masuk dalam kategori nonconforming dengan menggunakan metode FMEA. Tujuan penelitian ini adalah menganalisis faktor-faktor penyebab kecacatan dan menentukan alternatif solusi perbaikannya.

\section{Bahan dan Metode}

PT. DI merupakan perusahaan dengan sistem produksi make to order. Produk yang dihasilkan antara lain: pesawat terbang, helikopter, persenjataan, dan juga komponen atau part dari struktur pesawat terbang. Gambar 1. menunjukkan komponen penyusun struktur sayap (wing structure) pada pesawat jenis $\mathrm{CN}-235$, yang diproduksi oleh PT. DI. Penelitian ini dilakukan untuk mengetahui jumlah kecacatan yang terjadi pada komponen penyusun pesawat tipe $\mathrm{CN}-235$ dan penyebab yang terjadi adanya kecacatan pada komponen tersebut.

Pengumpulan data dilakukan dengan cara melakukan penelusuran data list scrap pada Fixed Wing Assembly Unit, PT. DI. Data yang diambil yaitu jumlah komponen ditolak (scrap) pada komponen untuk struktur sayap pesawat tipe $\mathrm{CN}-235$. 


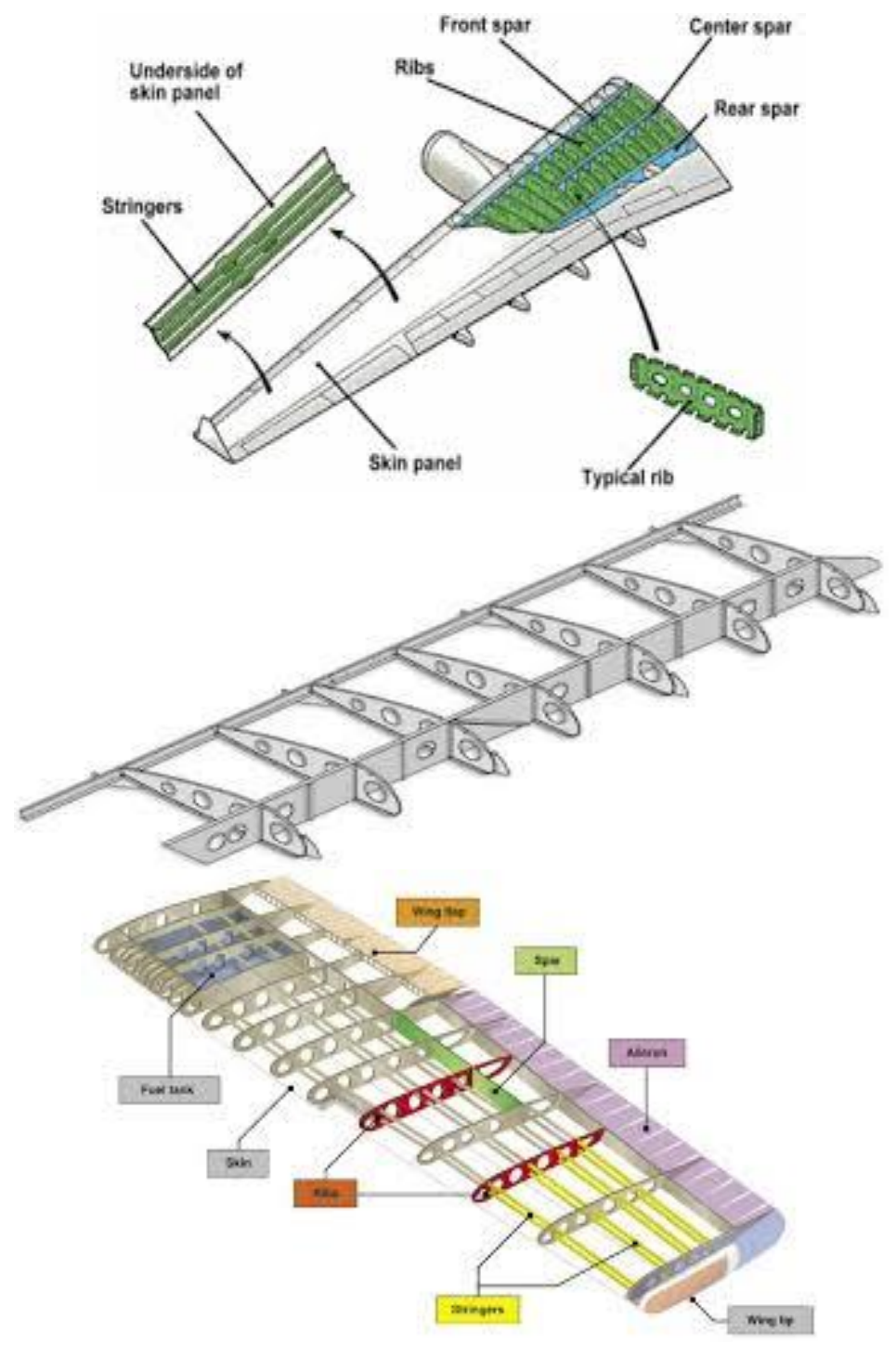

Gambar 1. Komponen pada Struktur Sayap CN-235

Data ini diperlukan untuk menentukan komponen yang paling banyak mengalami kecacatan, yang dilakukan dengan menggunakan histogram kemudian mencari penyebab dari adanya kecacatan pada komponen tersebut. Analisis selanjutnya menggunakan metode failure mode and effect analysis (FMEA) untuk mengetahui part yang harus dilakukan tindakan terlebih dahulu. Analisis dilakukan dengan memberikan penilaian terhadap tingkat keparahan (severity), tingkat potensi kejadian (occurrence), dan tingkat kesulitan melakukan deteksi (detection) (Carlson, 2014). Penentuan kriteria untuk nilai (rating) pada masing- masing aspek dilakukan dengan focus group discussion (FGD) dengan penyelia produksi, untuk mendapatkan rating penilaian yang sesuai dengan kondisi di tempat produksi.
Pada setiap jenis kegagalan yang terjadi pada komponen yang paling dominan mengalami kecacatan, dilakukan perhitungan risk priority number (RPN), yang dihasilkan dari persamaan berikut (Carlson, 2014):

$$
R P N=S \times O \times D
$$

dimana: $\mathrm{S}$ adalah nilai severity, $\mathrm{O}$ adalah nilai occurrence, dan D adalah nilai detection.

Setelah mengetahui tingkat resiko dari kegagalan yang terjadi, selanjutnya dilakukan analisis mengenai penyebab permasalahan serta langkah perbaikan untuk mencegah dan menghilangkan penyebab terjadinya kecacatan. 
Scrap part of $\mathrm{CN}-235$

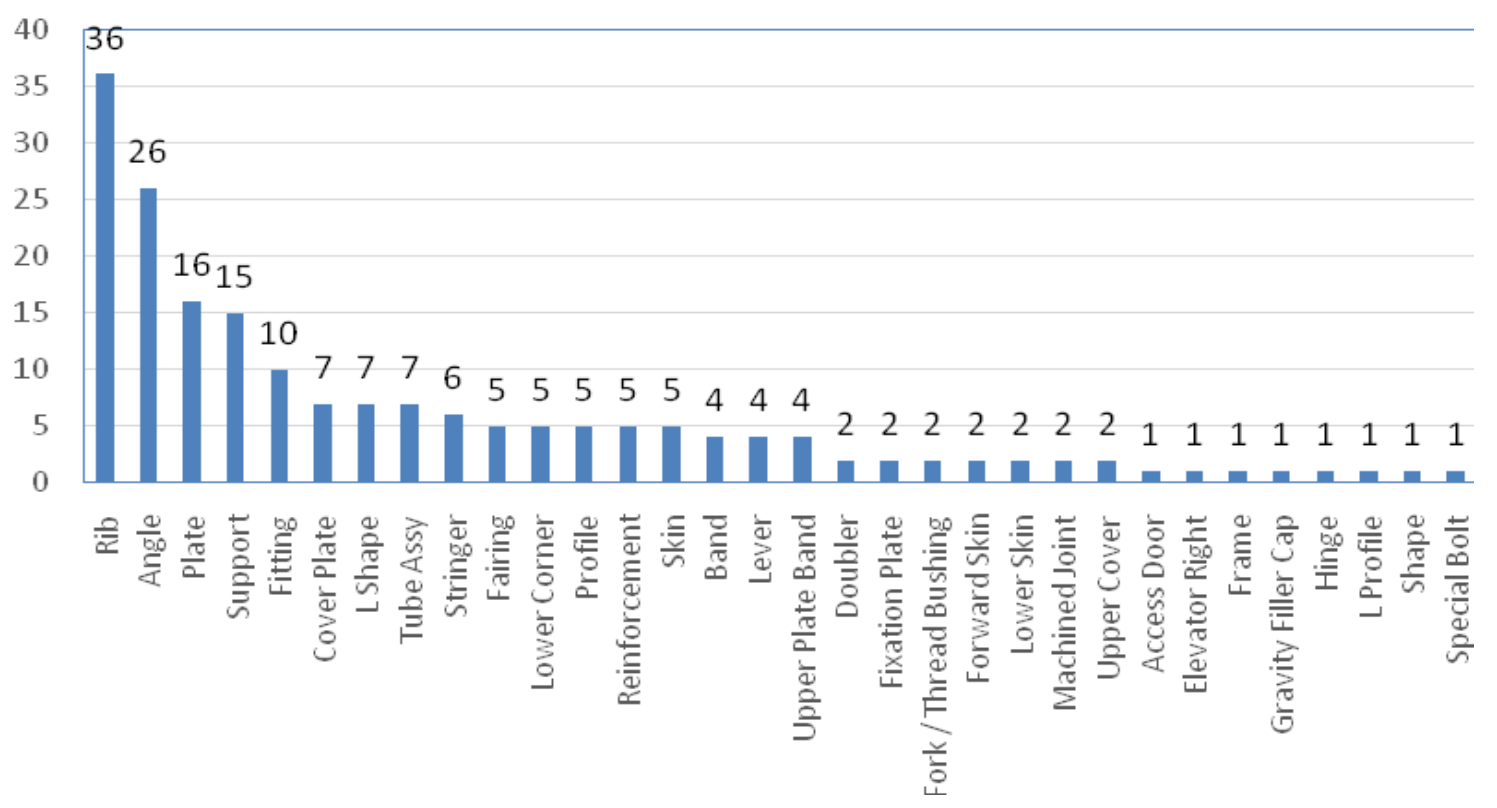

Gambar 2. Histogram Scrap Part dari CN-235 (2015 - 2016)

\section{Hasil dan Pembahasan}

Berdasarkan observasi dan diskusi yang dilakukan dengan operator dan penyelia pada fixed wing assembly unit, dalam penggabungan komponen masih terdapat ketidaksesuaian terhadap kualitas atau mutu dari komponen yang dihasilkan. Identifikasi terkait ketidaksesuaian yang terjadi (failure mode) dan faktor-faktor yang menyebabkan terjadinya nonconforming perlu dilakukan.

Data yang digunakan adalah data jumlah kecacatan pada part di fixed wing assembly unit pada kurun waktu tahun 2016-2017. Pengumpulan data dilakukan dengan cara melakukan pendataan list scrap pada proses pembuatan pesawat terbang jenis $\mathrm{CN}-235$. Data jumlah kecacatan pada part penyusun wing structure pesawat CN-235 tahun 2016-2017, dalam bentuk histogram diperlihatkan pada Gambar 2. Diketahui jumlah kecacatan pada tahun 2016-2017 adalah berjumlah 189 dari total kurang lebih 40.000 part yang dibutuhkan untuk memproduksi 2 buah pesawat CN-235 sesuai dengan pesanan.

Berdasarkan Gambar 2, dapat dilihat bahwa part yang sering mengalami kecacatan adalah pada komponen rib dengan jumlah kegagalan sebanyak 36 kejadian. Rib adalah komponen yang memiliki bentuk yang mengikuti penampang sayap (airfoil). Analisis part non-conforming pada artikel ini hanya dilakukan pada komponen yang sering mengalami kerusakan, yaitu komponen rib.

Pada tahap awal, dilakukan penentuan nilai atau rating untuk kondisi pada scrap part yang diamati.
Penentuan rating dilakukan dengan melakukan focus group discussion (FGD), yang meliputi tingkat keparahan (severity), tingkat kejadian (occurrence), dan tingkat keterpantauan (detection). Tingkat severity digunakan untuk mengidentifikasi dampak potensial dari kegagalan yang terjadi. Tingkat occurrence digunakan untuk menilai frekuensi terjadinya modus kegagalan. Adapun tingkat detection digunakan untuk menilai tingkat antisipasi terjadinya modus kegagalan yang akan terjadi.

Severity merupakan analisa untuk melakukan identifikasi dampak potensial kegagalan dengan cara melakukan penelitian pada akibat yang ditimbulkan oleh kegagalan tersebut. Akibat yang ditimbulkan dari kecacatan komponen rib terhadap wing structure memiliki nilai 1 sampai 10 , dimana nilai 1 diberikan jika tidak ada akibat yang ditimbulkan oleh kegagalan dan nilai 10 untuk kegagalan yang berakibat sangat fatal. Tabel 1 menunjukkan tingkat keparahan beserta kriteria dan nilainya.

Occurrence merupakan skala yang menunjukkan frekuensi terjadinya mode kegagalan. Hal ini juga dapat diartikan seberapa sering mode kegagalan tersebut terjadi. Tingkat frekuensi memiliki nilai 1 sampai 10, dimana nilai 1 diberikan pada jenis kegagalan yang hampir tidak pernah terjadi dan nilai 10 diberikan untuk jenis kegagalan yang hampir pasti terjadi. Tabel 2 menunjukkan tingkat kejadian beserta kriteria dan nilai yang diberikan pada jenis kegagalan tertentu. 
Tabel 1. Kriteria Penilaian Severity (Keparahan) (Carlson, 2014)

\begin{tabular}{llc}
\hline \multicolumn{1}{c}{ Tingkat Severity } & \multicolumn{1}{c}{ Kriteria } & Nilai \\
\hline Berbahaya tanpa peringatan & Efek moda kegagalan sangat fatal & 10 \\
\hline Berbahaya dengan peringatan & Efek moda kegagalan cukup fatal & 9 \\
\hline Sangat tinggi & Efek moda kegagalan sangat signifikan tidak bisa ditolerir & 8 \\
\hline Tinggi & Efek moda kegagalan sangat signifikan bisa ditolerir & 7 \\
\hline Sedang & Efek dari moda kegagalan sangat signifikan & 6 \\
\hline Rendah & Efek dari moda kegagalan cukup signifkan & 5 \\
\hline Sangat rendah & Efek dari moda kegagalan tidak terlalu signifikan & 4 \\
\hline Minor & Efek moda kegagalan cukup menggangu & 3 \\
\hline Sangat minor & Efek moda kegagalan tidak menggangu & 2 \\
\hline Tidak ada & Efek moda kegagalan tidak ada akibatnya & 1 \\
\hline
\end{tabular}

Tabel 2. Kriteria Penilaian Occurence (Kejadian) (Carlson, 2014)

\begin{tabular}{llcc}
\hline \multicolumn{1}{c}{ Tingkat Occurence } & \multicolumn{1}{c}{ Kriteria } & Skala & Nilai \\
\hline Hampir pasti & Kegagalan hampir pasti terjadi & $>18$ & 10 \\
\hline Sangat tinggi & Jumlah yang sangat tinggi dari kemungkinan kegagalan & $16--18$ & 9 \\
\hline Tinggi & Jumlah kegagalan cukup tinggi & $14--16$ & 8 \\
\hline Cukup tinggi & Jumlah kegagalan sedang & $12--14$ & 7 \\
\hline Sedang & Kemungkinan kegagalan hampir selalu ada & $10--12$ & 6 \\
\hline Rendah & Kemungkinana keggalan jarang ada & $8--10$ & 5 \\
\hline Sedikit kecil & Kemungkinan sedikit & $6--8$ & 4 \\
\hline Sangat kecil & Kemungkinan sangat sedikit & $4--6$ & 3 \\
\hline Jarang & Kemungkinan langka & $2--4$ & 2 \\
\hline Hampir tidak pernah & Kemungkinan hampir dipastikan tidak ada & $0--2$ & 1 \\
\hline
\end{tabular}

Tabel 3. Kriteria Penilaian Detection (Keterpantauan) (Carlson, 2014)

\begin{tabular}{llc}
\hline \multicolumn{1}{c}{ Tingkat Deteksi } & \multicolumn{1}{c}{ Kriteria } & Nilai \\
\hline Hampir tidak mungkin & Pengontrol tidak dapat mendeteksi kegagalan & 10 \\
\hline Sangat jarang & Sangat jauh kemungkinan pengontrol akan menemukan potensi kegagalan & 9 \\
\hline Jarang & Jarang kemungkinan pengontrol akan menemukan potensi kegagalan & 8 \\
\hline Sangat rendah & Kemungkinan pengontrol untuk mendeteksi kegagalan sangat rendah & 7 \\
\hline Rendah & Kemungkinan pengontrol untuk mendeteksi kegagalan rendah & 6 \\
\hline Sedang & Kemungkinan pengontrol untuk mendeteksi kegagalan sedang & 5 \\
\hline Agak tinggi & Kemungkinan pengontrol untuk mendeteksi kegagalan agak tinggi & 4 \\
\hline Tinggi & Kemungkinan pengontrol untuk mendeteksi kegagalan tinggi & 3 \\
\hline Sangat tinggi & Kemungkinan pengontrol untuk mendeteksi kegagalan sangat tinggi & 2 \\
\hline Hampir pasti & Kegagalan dalam proses tidak dapat terjadi karena telah dicegah melalui & 1 \\
& desain solusi & \\
\hline
\end{tabular}

Detection adalah penilaian yang menunjukkan kemungkinan metode kegagalan lolos dari tahap pengawasan dan pendeteksian kerusakan, atau merupakan tahap yang menunjukkan tingkat kesulitan dalam pendeteksian kegagalan. Tingkat kemungkinan melakukan deteksi kegagalan diberikan nilai 1 sampai 10, dimana nilai 1 diberikan pada solusi deteksi sistematis yang tidak memungkinkan terjadinya kegagalan dan nilai 10 untuk kondisi sistem yang tidak memungkinkan melakukan deteksi kegagalan. Tabel 3 menunjukkan kriteria tingkat deteksi oleh sistem untuk mengantisipasi kegagalan dan nilai yang diberikan.

Berdasar pengamatan yang dilakukan untuk kecacatan komponen rib pada struktur sayap pesawat, telah ditemukan 5 (lima) jenis modus kegagalan, yang meliputi: rib rusak, ukuran rib berbeda, rivet tidak dapat dipasang, rib sulit dirakit, dan rib yang tidak sesuai. Rib yang rusak, disebabkan oleh jarak lubang yang terlalu dekat dengan batas. Keadaan tersebut dapat mengakibatkan turunnya kekuatan pada struktur sayap dan dapat mengakibatkan terjadinya robek pada sayap pesawat. Hal tersebut dinilai memiliki tingkat keparahan yang membahayakan dan fatal, sehingga mendapatkan nilai 10 dari aspek keparahan yang ditimbulkan karena kecacatan rib yang rusak. Tabel 4 menunjukkan penilaian tingkat keparahan pada struktur sayap yang diakibatkan oleh semua modus kegagalan. Dapat dilihat pada Tabel 4 tersebut, semua jenis modus kegagalan dinilai memiliki tingkat keparahan maksimal untuk efek kegagalan yang dihasilkan, dengan nilai 10. Semua modus kegagalan dinilai dapat mengakibatkan kerusakan pada struktur sayap dan itu akan berakibat fatal pada keselamatan penerbangan.

Tingkat kejadian (occurrence) untuk tiap jenis modus kegagalan berada pada nilai yang berbeda. Perbedaan nilai berdasarkan frekuensi terjadinya jenis 
kegagalan selama masa periode pengamatan. Rib rusak ditemukan terjadi sebanyak 3 kali, dan kemudian diberikan nilai 2. Tabel 5 menunjukkan frekuensi terjadinya masing-masing jenis kegagalan dan tingkat nilai yang diberikan untuk tiap modus kegagalan. Modul kegagalan rib yang tidak sesuai paling banyak terjadi, yaitu 15 kali, dan diberikan nilai occurance sebesar 8. Adapun modus kegagalan ukuran rib berbeda merupakan modus yang paling jarang terjadi, yaitu hanya 2 kali, dan diberikan nilai occurance sebesar 1.

Tabel 4. Penilaian Severity untuk Komponen Rib

\begin{tabular}{|c|c|c|c|c|}
\hline No & Modus Kegagalan & Penyebab Kegagalan & Efek kegagalan & Nilai \\
\hline 1 & Rib rusak & $\begin{array}{l}\text { Jarak lubang terlalu mendekati } \\
\text { batas }\end{array}$ & $\begin{array}{l}\text { Melemahkan struktur sayap dan dapat terjadi } \\
\text { robek pada sayap pesawat }\end{array}$ & 10 \\
\hline 2 & $\begin{array}{l}\text { Ukuran rib } \\
\text { berbeda }\end{array}$ & Kelebihan pemotongan & $\begin{array}{l}\text { Jarak rivet menjadi lebih dekat yang } \\
\text { mengakibatkan melemahnya struktur sayap } \\
\text { pesawat dan tidak sesuai standar }\end{array}$ & 10 \\
\hline 3 & $\begin{array}{l}\text { Rivet tak dapat } \\
\text { dipasang }\end{array}$ & $\begin{array}{l}\text { Lubang rivet antar part yang } \\
\text { berbeda. Terdapat perbedaan titik } \\
\text { center pada kedua lubang }\end{array}$ & $\begin{array}{l}\text { Rib tidak dapat disatukan dengan part lain } \\
\text { untuk membentuk struktur sayap pesawat }\end{array}$ & 10 \\
\hline 4 & Rib sulit dirakit & $\begin{array}{l}\text { Miss match antar part pada saat } \\
\text { dirakit }\end{array}$ & $\begin{array}{l}\text { Struktur part tidak rapat/ terdapat celah yang } \\
\text { mampu mengakibatkan ketidakseimbangan } \\
\text { sayap }\end{array}$ & 10 \\
\hline 5 & Rib tidak sesuai & Pemasangan rib tidak rata & $\begin{array}{l}\text { Terjadi turbulensi karena aliran udara tidak } \\
\text { mulus (smooth) }\end{array}$ & 10 \\
\hline
\end{tabular}

Tabel 5. Penilaian Occurrence pada Kecacatan Rib

\begin{tabular}{clcc}
\hline No & Modus Kegagalan & Frekuensi Kecacatan & Nilai \\
\hline 1 & Rib rusak & 3 & 2 \\
\hline 2 & Ukuran rib berbeda & 2 & 1 \\
\hline 3 & Rivet tidak dapat dipasang & 12 & 6 \\
\hline 4 & Rib sulit dirakit & 4 & 2 \\
\hline 5 & Rib tidak sesuai & 15 & 8 \\
\hline
\end{tabular}

Tabel 6. Penilaian Detection untuk Komponen Rib

\begin{tabular}{cllc}
\hline No & \multicolumn{1}{c}{ Modus Kegagalan } & Kendali Proses Saat Ini & Nilai \\
\hline 1 & Rib rusak & Deteksi visual dan perhitungan oleh operator rendah & 6 \\
\hline 2 & Ukuran rib berbeda & Deteksi visual dan perhitungan oleh operator sedang & 5 \\
\hline 3 & Rivet tidak dapat dipasang & Deteksi visual dan perhitungan oleh operator sedang & 5 \\
\hline 4 & Rib sulit dirakit & Deteksi visual dan dengan filler gauge tool & 3 \\
\hline 5 & Rib tidak sesuai & Deteksi visual dan dengan locator tool & 4 \\
\hline
\end{tabular}

Tabel 7. Risk Priority Number (RPN) untuk Kecacatan Rib

\begin{tabular}{|c|c|c|c|c|c|c|}
\hline No & Failure Mode & Effect & $S$ & $\boldsymbol{O}$ & $D$ & $R P N$ \\
\hline 1 & Rib tidak sesuai & Terjadi turbulensi karena aliran udara tidak smooth & 10 & 8 & 4 & 320 \\
\hline 2 & $\begin{array}{l}\text { Rivet tidak } \\
\text { dapat dipasang }\end{array}$ & $\begin{array}{l}\text { Rib tidak dapat disatukan dengan part lain untuk membentuk } \\
\text { struktur sayap pesawat }\end{array}$ & 10 & 6 & 5 & 300 \\
\hline 3 & Rib rusak & $\begin{array}{l}\text { Melemahkan struktur rangka dan dapat terjadi robek pada } \\
\text { sayap pesawat }\end{array}$ & 10 & 2 & 6 & 120 \\
\hline 4 & Rib sulit dirakit & $\begin{array}{l}\text { Struktur part tidak rapat/ terdapat celah yang mampu } \\
\text { mengakibatkan ketidakseimbangan sayap }\end{array}$ & 10 & 2 & 3 & 60 \\
\hline 5 & $\begin{array}{l}\text { Ukuran rib } \\
\text { berbeda }\end{array}$ & $\begin{array}{l}\text { Jarak rivet menjadi lebih dekat yang mengakibatkan } \\
\text { melemahnya struktur sayap pesawat dan tidak sesuai standar }\end{array}$ & 10 & 1 & 5 & 50 \\
\hline
\end{tabular}

Tingkat keterpantauan (detection) untuk tiap jenis modus kegagalan berada pada nilai yang berbeda. Nilai tingkat keterpantauan ini didasarkan tingkat kesulitan dalam mengamati terjadinya modus kecacatan. Rib rusak terpantau dengan melakukan deteksi visual dengan kesulitan rendah dalam perhitungan oleh operator, dan diberikan nilai 6 .
Ukuran rib yang berbeda dan rivet tidak dapat dipasang dapat diketahui dengan deteksi visual dengan tingkat perhitungan oleh operator yang sedang, sehingga diberikan nilai 5. Tabel 6 menunjukkan penilaian keterpantauan masing-masing jenis kegagalan dan tingkat nilai yang diberikan untuk tiap modus kegagalan. 
Tabel 8. FMEA untuk Kecacatan Komponen Rib pada Wing Structure Pesawat CN-235

\begin{tabular}{|c|c|c|c|c|}
\hline No & $\begin{array}{c}\text { Failure } \\
\text { Mode }\end{array}$ & RPN & Tindakan & Saran \\
\hline 1 & $\begin{array}{l}\text { Rib tidak } \\
\text { sesuai }\end{array}$ & 320 & $\begin{array}{l}\text { Apabila hanya terdapat satu atau dua } \\
\text { yang tidak sesuai, maka dapat melakukan } \\
\text { pemasangan shim (pengganjal khusus) } \\
\text { atau perlu dilakukan pergantian sebagian } \\
\text { rib }\end{array}$ & \multirow{5}{*}{$\begin{array}{l}\text { Perlakuan tindakan dilakukan sesuai } \\
\text { dengan kesepakatan forum engineer, } \\
\text { sebab apabila diberikan dubbler } \\
\text { ataupun shim, efeknya adalah adanya } \\
\text { penambahan beban pada struktur } \\
\text { pesawat terbang, hal tersebut tetap } \\
\text { mampu menurunkan kualitas dan } \\
\text { performa dari pesawat, sehingga perlu } \\
\text { dilakukan tindakan lebih lanjut } \\
\text { dengan cara melakukan inspeksi yang } \\
\text { lebih ketat pada bagian (special part) } \\
\text { serta melakukan analisa terhadap } \\
\text { faktor-faktor lain seperti ( manusia, } \\
\text { prosedur, lingkungan dll) agar } \\
\text { kecacatan tidak dapat terjadi }\end{array}$} \\
\hline 2 & $\begin{array}{l}\text { Rivet tidak } \\
\text { dapat } \\
\text { dipasang }\end{array}$ & 300 & $\begin{array}{l}\text { Apabila hanya terdapat satu atau dua } \\
\text { yang tidak pas, maka dapat melakukan } \\
\text { dubbler kepada salah satu part atau } \\
\text { menambalnya kemudian dilakukan } \\
\text { pengeboran lagi }\end{array}$ & \\
\hline 3 & $R i b$ rusak & 120 & $\begin{array}{l}\text { Apabila hanya terdapat satu atau dua } \\
\text { yang mendekati batas, maka dapat } \\
\text { melakukan dubbler atau menambalnya } \\
\text { kemudian membuat lubang baru }\end{array}$ & \\
\hline 4 & $\begin{array}{l}\text { Rib sulit } \\
\text { dirakit }\end{array}$ & 60 & $\begin{array}{l}\text { Apabila hanya terdapat satu atau dua } \\
\text { yang miss match, maka dapat melakukan } \\
\text { pemasangan shim (pengganjal khusus) } \\
\text { atau dengan perlakuan rework/repair } \\
\text { pada part tertentu }\end{array}$ & \\
\hline 5 & $\begin{array}{l}\text { Ukuran rib } \\
\text { berbeda }\end{array}$ & 50 & $\begin{array}{l}\text { Melakukan rework dengan cara membuat } \\
\text { special part yang berukuran lebih besar/ } \\
\text { panjang }\end{array}$ & \\
\hline
\end{tabular}

Berdasarkan tiga kriteria di atas, dapat diperhitungkan tingkat prioritas penanganan resiko dari kegagalan yang muncul. Perhitungan tingkat prioritas resiko (risk priority number $=\mathrm{RPN}$ ), dilakukan dengan perkalian dari hasil severity, occurrence, dan detection, sebagaimana persamaan (1). Dengan persamaan tersebut, dapat diperkirakan bahwa semakin besar nilai RPN berarti bahwa tingkat prioritas penanganan resiko juga semakin besar. Tabel 7 menunjukkan hasil perhitungan nilai RPN untuk tiap jenis modus kegagalan. Rib tidak sesuai merupakan jenis kegagalan yang memiliki nilai RPN paling besar, yaitu 320. Hal tersebut menunjukkan bahwa jenis kegagalan rib tidak sesuai mendapatkan prioritas untuk penanganan, jika dibandingkan dengan jenis modus kegagalan yang lainnya. Sedangkan modus kegagalan berupa ukuran rib berbeda menempati urutan prioritas terakhir, dengan nilai paling rendah, yaitu 50 poin.

Dengan memperhatikan nilai RPN untuk masingmasing jenis kegagalan, dilakukan diskusi dengan pendekatan failure modes and effect analysis (FMEA) untuk menentukan tindakan yang perlu diambil untuk menangani kegagalan yang terjadi. Tabel 8 menunjukkan tindakan yang perlu dilakukan untuk menangani modus kegagalan.

Berdasarkan Tabel 8, dapat diketahui beberapa tindakan yang perlu dilakukan apabila terdapat satu atau dua part yang terkena kecacatan atau kegagalan, seperti memberikan shim atau pengganjal khusus. Pemberian dubbler dan pembuatan komponen khusus, namun perlakuan tindakan dilakukan sesuai dengan kesepakatan forum engineer. Pemberian dubbler ataupun shim memberikan pengaruh berupa penambahan beban pada struktur pesawat terbang. Hal tersebut dapat menurunkan kualitas dan performa dari pesawat terbang, sehingga perlu dilakukan tindakan lebih lanjut. Hal-hal yang dapat dilakukan diantaranya dengan melakukan inspeksi yang lebih ketat pada bagian special part, serta melakukan analisa terhadap faktor-faktor lain seperti operator, prosedur, lingkungan, dan lain-lain, agar kecacatan tidak dapat terjadi.

\section{Kesimpulan}

Dari berbagai komponen yang masuk ke dalam kategori cacat, pada pembuatan wing structure 2 buah pesawat CN235 yang dikerjakan pada tahun 20152016, komponen rib memiliki jumlah kecacatan paling tinggi yakni sebesar 36 buah. Berbagai jenis kecacatan pada komponen rib berpengaruh sangat fatal terhadap kekuatan struktur sayap. Dengan mempertimbangkan pula frekuensi kejadian dan tingkat pendeteksian, nilai potensi resiko dari kegagalan rib paling tinggi diperoleh pada jenis kegagalan rib yang tidak sesuai. Berdasarkan metode FMEA dapat diketahui beberapa tindakan yang perlu dilakukan, yaitu dengan melakukan inspeksi yang lebih ketat pada bagian komponen khusus serta melakukan analisa terhadap faktor-faktor lain, seperti operator, prosedur, lingkungan, dan lain-lain.

\section{Daftar Pustaka}

Agnihothri, S.; Kenett, R. (1995). "The impact of defects on a process with rework". European Journal of Operational Research. Vol. 80, pp. 308-327. 
Bala, I.; Sharma, S.K.; Kumar, S.; Shrivastava, R. (2014). "Exploring safety aspects of aviation industry". Advances in Aerospace Science and Applications, Vol. 4 (1), pp. 37 - 44.

Banduka, N.; Veža, I.; Bilić, B. (2016). An integrated lean approach to process Failure Mode and Effect Analysis (PFMEA): A case study from automotive industry". Advances in Production Engineering \& Management, Vol. 11 (4), pp. 355-365.

Carlson, C.S. (2014). Understanding and Applying the Fundamentals of FMEAs. Tutorial Notes on 2014 Annual Reliability and Maintainability Symposium (AR\&MS). ReliaSoft Corporation.

Chen, Y.C. (2013). "Optimal production and inspection strategy with inspection time and reworking for a deteriorating process". International Journal of Operations Research, Vol. 10 (3), pp. 123-133.

Darmawan, A.; Rapi, A.; Ali, S. (2016). "Analisis perawatan untuk mendeteksi risiko kegagalan komponen pada excavator 390D”. Jurnal Ilmiah Teknik Industri, Vol.15 (1), 109 - 115
Ezeanyim, O.C.; Onwurah, U.O.; Okoli, N.C.; Okpala, C.C. (2015). "An evaluation of actual costs of rework and scrap in manufacturing industry". Journal of Multidisciplinary Engineering Science and Technology (JMEST), Vol. 2 (4), 612 - 618.

Hanif, R. Y., Rukmi, H. S. and Susanty, S. (2015). "Perbaikan kualitas produk keraton luxury di PT. $\mathrm{X}$ dengan menggunakan metode failure mode and effect analysis dan fault tree analysis". Jurnal Online Institut Teknologi Nasional, Vol. 3(3), pp. $137-147$.

Nastiti, H. (2013). “Analisis pengendalian kualitas produk dengan metode statistical quality control (Studi Kasus: pada PT “X” Depok)'. Prosiding Seminar Nasional Sustainable Competitive Advantages (SCA) 2014, pp. $414-423$.

Puspitasari, N.B.; Martanto, A. (2014). "Penggunaan FMEA dalam mengidentifikasi resiko kegagalan proses produksi sarung ATM (Alat Tenun Mesin) (Studi kasus PT. Asaputex Jaya Tegal)", Jurnal Teknik Industri Undip, Vol 9 (2), 93 - 98.

Stamatis, D.H. (2003). Failure Mode and Effect Analysis: FMEA from Theory to Execution. (2 Rev Exp Edition). USA: Amer Society for Quality. 